\title{
CEBONG, KAMPRET, DAN KADRUN DALAM KONTESTASI PILPRES 2019: TINJAUAN KESELARASAN ANTARA TEORI SPEAKING DENGAN OOE MAU BICARA
}

\author{
M. Wildan \\ Program Studi Sastra Indonesia, Fakultas Sastra, Universitas Pamulang \\ dosen00278@unpam.ac.id
}

\begin{abstract}
ABSTRAK
Tulisan ini bertujuan untuk menjelaskan bahwa kontestasi Pilpres 2019 paling tidak telah memproduksi tiga leksikon: cebong, kampret, dan kadrun. Ketiga leksikon ini menjadi viral penggunaannya di kalangan pendukung atau simpatisan pasangan Joko Widodo - Ma'ruf Amin dan Prabowo Subianto - Sandiaga Salahuddin Uno dalam rangka elektabilitas serta popularitas pasangan calon. Terseretnya leksikon cebong, kampret, dan kadrun ke arus politik Pilpres 2019 tentu secara latar psikologis (scene) dan partisipan (participants) tidak bisa dinapikan dari pendulangan suara antar pasang calon. Dengan demikian, cebong, kampret, dan kadrun merupakan leksikon apolitik yang politik serta memungkinkan sekali dikaji dari sudut teori SPEAKING sebagaimana yang dipelopori oleh Dell Hymes serta terbuka peluang untuk diselaraskan dengan teori yang dikembangkan oleh Soepomo Poedjasoedarmo berupa OOE MAU BICARA. Tulisan ini menggunakan metode deskriptif kualitatif dengan menerapkan dua teknik, yaitu: teknik catat dan teknik dokumentasi. Teknik catat dapat diterapkan pada pemerolehan data secara virtual melalui tangkapan layar (screen shoot) dari media daring atau mencatat ke dalam kartu data. Adapun teknik dokumentasi dapat diaplikasikan melalui pendokumentasian pada sejumlah koran seperti antara lain: harian Kompas, Republika, Sindo, Warta Kota, dan Tangerang Raya. Tulisan ini menyimpulkan bahwa kemenangan pasangan Joko Widodo-Ma'ruf Amin termasuk kemenangan bahasa yang dikontestasikan di ruang media daring dan luring yang termanipestasikan ke dalam sendi-sendi SPEAKING serta OOE MAU BICARA.
\end{abstract}

Kata Kunci: cebong, kampret, kadrun, SPEAKING, OOE MAU BICARA

\section{PENDAHULUAN}

Apa yang teristimewa dari Pilpres 2019? Hemat saya, menjadi pertanyaan penggugah dalam rangka mengawali tulisan sederhana ini. Pasalnya, Pilpres 2019 tidak sekadar penentuan seputar pemilihan orang nomor 1 dan 2 di Indonesia serta menang dan kalah, melainkan ada aspek lainnya yaitu mengenai fakta bahasa. Ketika Pilpres 2019 mengetengahkan isu-isu politik dan ekonomi menjadi hal yang biasa, namun Pilpres yang menyuguhkan fakta bahasa inilah yang menjadi titik keistimewaannya. Di samping data menunjukkan bahwa dalam perspektif linguistik ternyata Pilpres 2019 telah menciptakan fakta bahasa baru. Adapun fakta bahasa baru itu setidaknya ada tiga yang belakangan ini menjadi viral di tengah masyarakat yaitu: cebong, kampret, dan kadrun.

Meskipun disadari bahwa pemilihan presiden yang digelar 2019 telah usai, namun sisa kontestasi perebutan orang nomor 1 dan 2 di Indonesia tersebut masih terasa hingga hari ini. Paling tidak masyarakat terpolakan menjadi dua sisi. Satu sisi terdapat masyarakat yang pro terhadap 01 Joko Widodo - Ma'ruf Amin dan sisi lainnya yang pro terhadap 02 Prabowo Subianto - Sandiaga Salahuddin Uno. Bekas polarisasinya terkonfirmasi melalui fakta bahasa: cebong, kampret, dan kadrun. Terlihat nyata dalam judul pemberitaan, media sosial, serta 
komentar warganet terhadap suatu pemberitaan yang memang ketiga fakta bahasa itu kerap digunakan dalam berbagai kesempatan pada dinamika Pilpres 2019.

Harus diakui pula, pemilihan presiden 2019 tidak sekadar menyisahkan dinamika politik serta intriknya, melainkan juga fakta bahasa. Hal itu ditandai oleh kehadiran leksikon cebong, kampret, dan kadrun ke ruang publik. Bahkan cebong, kampret, dan kadrun menjadi sangat viral di sejumlah lini media massa. Keviralannya tentu cukup berdasar karena telah menjadi kosakata kalangan elit pendukung pasangan Joko Widodo - Ma'ruf Amin dan Prabowo Subianto - Sandiaga Uno. Cebong, kampret, dan kadrun telah terkonseptualisasi dalam benak penutur dan mitra tutur bangsa Indonesia. Untuk itu, pada laman google sebagai mesin pencari merilis dalam hitungan 0,49 detik terdapat 3.260.000 artikel yang mengulas cebong. Sementara cebong juga diulas oleh laman google dalam hitungan 0,47 detik menemukan sebanyak 5.990.000 artikel tentang cebong. Mencermati ulasan google terhadap kedua leksikon ini dapat dijelaskan bahwa Pilpres 2019 menemukan dinamika fakta bahasanya yang telah mengideologi antar partisipan.

Dalam pada itu, cebong, kampret, dan kadrun telah menjadi ideologi bahasa bagi publik Indonesia, terutama bagi pendukung pasangan Joko Widodo-Ma'ruf Amin dan Prabowo Subianto-Sandiaga Uno. Esensinya, ideologi bahasa dalam pandangan Judith T. Irvine dalam Oxford Bibliographies daring bahwa: "Language ideologies are conceptualizations about language, speakers, and discursive practices. Like other kinds of ideologies, language ideologies are pervaded with political and moral interests and are shaped in a cultural setting" (Lih. www.oxfordbibliographies.com). Benang merah yang dapat ditarik dari pernyataan Judith T. Irvine ialah bahwa ideologi bahasa sarat dengan intrik-intrik politik dan moral yang terbentuk dalam lingkungan kebudayaan yang bernama ekologi bahasa. Sejatinya, ekspresi leksikon cebong, kampret, dan kadrun menjadi intrik politik kalangan elit dalam rangka pendulangan suara. Meskipun keduanya sama sekali tidak tercatat dalam kamus politik, tetapi cebong yang dialamatkan kepada pasangan Joko Widodo - Ma'ruf Amin dan kampret dan kadrun dialamatkan kepada Prabowo Subianto - Sandiaga Uno ini telah menjadi dinamika politik tanah air pra dan pasca Pilpres 2019 lalu.

Andailah disepakati cebong, kampret, dan kadrun sebagai ideologi bahasa pada kontestasi Pilpres 2019, maka kedua kata ini telah menjadi identitas bagi pendukung pasang calon. Hal ini memang senada yang disampaikan oleh Diana J. Arya, dkk. (2015:4) dalam Language Ideologies and Literacy Achievement: Six Multilingual Countries and Two International Assesments bahwa ideologi bahasa itu sebagai penciri indentitas suatu kelompok dalam rangka menemukan persamaan dan perbedaannya. Pandangan senada juga disampaikan 
oleh Fahrurrozi dan Andri Wicaksono (2016 :10) bahwa "ideologi bahasa memengaruhi pemahaman kita akan sesuatu yang biasa; namun juga membentuk konstelasi suatu pemahaman mengenai bahasa dan bahasa dalam penggunaannya."

Meskipun Pilpres sudah berlalu dua tahun lebih, tetapi tampaknya leksikon cebong, kampret, dan kadrun hingga kini masih menjadi viral di jagat maya. Benih-benih retaknya hubungan pendukung pasangan calon 01 dan 02 ternyata belum terekonsiliasi, walaupun disadari dengan sunguh-sungguh bahwa Prabowo Subianto selaku penantang Joko Widodo pada Pilpres lalu telah bergabung dalam koalisi pemerintahan Joko Widodo. Dengan diberikan jabatan sebagai Menteri Pertahanan (Menhan) menjadi suatu keniscayaan bahwa di tingkat elit sudah tidak ada perpecahan, namun pada akar rumput disparitas tersebut masih ada.

Adapun yang menjadi permasalahan utama tulisan ini ialah bagaimana dinamika penggunaan leksikon cebong, kampret, dan kadrun dalam kontestasi Pilpres 2019 bila ditinjau dari teori SPEAKING serta OOE MAU BICARA? Di samping saya juga menyelaraskan teori SPEAKING dengan teori OOE MAU BICARA prihal menyingkap data seputar penggunaan ketiga leksikon cebong, kampret, dan kadrun dalam dinamika Pilpres 2019 lalu.

\section{METODE}

Tulisan yang mengkaji bentuk fakta bahasa yang terindikasi ideologi bahasa pada dinamika Pilpres 2019 ini termasuk hasil penelitian deskriptif kualitatif. Untuk menunjang tulisan ini penulis menggunakan dua data primer yaitu: (1) data yang dihimpun melalui publik daring seperti fakta kebahasaan yang ditelusuri melalui google dan media sosial. (2) data yang dihimpun melalui publik luring berupa arsip yang tersimpan di dalam sejumlah laman berita daring dan luring, seperti Harian Kompas, Harian Republika, Warta Kota, Jawa Pos, www.detik.com, kompas.id, www.kompas.com, www.republika.co.id, dan sejumlah laman terkait lainnya. Penelusuran data dengan menggunakan kedua pendekatan ini sebagai upaya proses pencarian data secara valid. Di samping metode trianggulasi berupa akun media sosial para tokoh politikus terkait komentarnya pada saat kampanye terjadi juga dijadikan pertimbangan dalam proses pemerolehan data.

Sementara pengumpulan data dilakukan dengan menggunakan teknik catat, studi dokumentasi, dan wawacara mendalam. Teknik catat, dimaksudkan bahwa dalam studi kebahasaan mencatat fakta bahasa menjadi suatu keharusan sehingga mendapat orisinalitas data. Tentu pencatatan tidak serta-merta dimaknai sebagai pencatatan dengan mengunakan pensil dan bolpoin di atas kertas atau kartu data. Pencatatan dalam konteks penelitian ini lebih pada pemanfaatan media teknologi, seperti screen shoot (tangkapan layar) terhadap data yang terdapat di laman media massa atau akun media sosial. Selanjutnya, hasil screen shoot 
(tangkapan layar) gawai maupun laptop dipindahkan ke dalam lembar kerja Microsoft Word atau Power Point (salindia). Di samping data juga dicatat dengan menggunakan notepad guna merekam informasi kekinian yang tersedia dalam sumber data.

Sementara itu, studi dokumentasi diperlukan untuk membuka kembali data yang telah peneliti lakukan terdahulu. Dengan cara ini dapat dilakukan perbandingan data terdahulu dengan data yang diperoleh kekinian. Sebagaimana disebutkan terdahulu bahwa peneliti telah melakukan penelitian yang sejenis, namun dengan dikembangkan lagi penelitian ini paling tidak akan menemukan ideologi bahasa dalam tuturan para pendukung kontestan. Berhubung penelitian ini dilakukan pada tahun 2021, maka studi dokumentasi data digital menjadi sesuatu yang mesti dijadikan pertimbangan utama guna mendapatkan data. Artinya, Pilpres 2019 telah dilaksanakan satu tahun lebih. Sementara data secara umum telah diproduksi. Oleh karenanya, jalan terakhirnya adalah dengan membuka jejak digital Pilpres 2019 lalu menjadi solusi utamanya. Adapun pemunculan teknik wawancara hanya sebagai suatu langkah trianggulasi guna mendapatkan data yang valid.

\section{HASIL DAN PEMBAHASAN}

Pada poin hasil dan pembahasan ini saya akan menyelaraskan antara teori SPEAKING yang dikemukakan oleh Dell Hymes (1974) dengan teori OOE MAU BICARA ${ }^{1}$ yang kemukakan oleh Soepomo Poedjasoedarmo (1985). Teori OOE MAU BICARA merupakan pengembangan dari teori SPEAKING. Dalam hemat saya keduanya perlu dilakukan penyelarasan guna menemukan keselarasan pada masing-masing fonem seperti antara lain terdapat kesamaan S setting pada SPEAKING dengan A Adegan Tutur pada OOE MAU BICARA yang sama-sama merujuk tempat, waktu, dan peristiwa tutur. Dalam hemat saya, teori yang dikembangkan oleh Poedjasoedarmo merupakan pengembangan dari teori yang disampaikan oleh Hymes. Hal ini tampak secara fonem memiliki jumlah yang tidak sama: 8 berbanding 12 , meskipun demikian namun secara subtansi terdapat persamaan. ${ }^{2}$

\footnotetext{
${ }^{1}$ OOE MAU BICARA adalah memoteknik dari: O orang ke-1 atau penutur, O orang ke-2 atau mitra tutur, E warna emosi O1, M maksud dan tujuan percakapan, A adanya $O 3$ dan barang-barang lain di sekeliling adegan percakapan, $U$ urutan tutur, B bab yang dipercakapkan; pokok pembicaraan, I instrument atau sarana tutur, $C$ citarasa tutur, A adegan tutur, $R$ register khusus atau bentuk wacana atau genre tutur, dan $A$ aturan atau norma kebahasaan lain. (Lih. Baryadi, 397 : 2013).

${ }^{2}$ Bila merujuk Foundation in Sosiolinguistics: An Ethnographic Approach karya Dell Hymes tahun 1974 bahwa pertama kali Hymes menggunakan 16 komponen tutur, yaitu: message form, message content, setting, scene, speaker or sender, addressor, hearer, or receiver, or audience, addressee, purpose, outcomes, purpusesgoals, key, channels, forms of speech, norms of interaction, norm of interpretation, dan genres. Namun, oleh Hymes (1989) dalam artikelnya yang berjudul Models of the Interaction of Language and Social Life dalam karya bersama John J. Gumperz yang berjudul Directions in Sociolinguistics: The Ethnography of Communication lebih baik disederhanakan menjadi SPEAKING. Untuk itu, hingga saat ini teori SPEAKING menjadi masyhur di kalangan penggiat bahasa, terkhusus sosiolinguistik.
} 
Harus diakui bahwa pola komunikasi yang terjadi dalam Pilpres 2019 tidak bisa dilepaskan dari dimensi SPEAKING. Dimensi SPEAKING melingkupi konteks pembicaraan saat diujarkan antara penutur dan lawan tutur. Pembicaraan yang menghasilkan fakta bahasa berupa cebong, kampret, dan kadrun tidak lahir di ruang hampa dengan tanpa disertai konteks tuturan yang menyertainya. Dalam hemat saya, SPEAKING mengambil peran dalam rangka menyertai konteks tuturan antara penutur dan lawan tutur. Bahkan memungkinkan sekali leksikon cebong, kampret, dan kadrun diujarkan oleh pendukung pasang calon karena ada sangkut pautnya dengan partisipan atau orang ke-1, orang ke-2, orang ke-3, dan urutan bicara yang saling memengaruhi. Oleh karenanya, menjadi penting untuk dilakukan penyelarasan antar teori yang ada.

\section{S : Setting dan Scence \|A : Adegan Tutur}

Setting dan scence dapat diselaraskan dengan adegan tutur. Keduanya sama-sama merujuk pada tempat, waktu, dan peristiwa tutur. Dalam konteks fakta bahasa Pilpres 2019 menunjukkan bahwa tempat tuturannya jamak terjadi secara virtual. Pasalnya, penelitian ini mengambil data secara khusus di sejumlah laman dan media sosial. Untuk itu, tempat terjadinya tuturan Pilpres 2019 berlangsung secara daring. Hal ini tentu tidak bersifat monopoli bahwa pemakaian leksikon cebong, kampret, dan kadrun hanya secara virtual.

Pola pembentukan tuturannya bermula dari saling komentar antar pendukung JokowiMa'ruf dengan Prabowo-Sandi. Bahkan sebagai fakta bahasa lainnya bermula dari komentar pendukung Jokowi-Ma'ruf dengan Prabowo-Sandi terhadap suatu wacana pemberitaan tentang pasangan calon. Dengan demikian sulit terhindari munculnya fakta bahasa berupa cebong, kampret, dan kadrun di dalam suatu peristiwa tutur.

Sementara dari dimensi scence lebih pada latar psikologis tuturan tersebut diujarkan. Dalam pengamatan saya, sejak dideklarasikan oleh Komisi Pemilihan Umum (KPU) sebagai kontestan Pilpres 2019 menjadi cikal-bakal bermuculan fakta bahasa cebong, kampret, dan kadrun di sejumlah laman media sosial dan media masa. Hal ini menggambarkan suasana psikologis penutur atau warganet yang telah terpolarisasi sebagai pendukung Jokowi-Ma'ruf dan Prabowo-Sandi. Polarisasi tuturan itu ditandai dengan leksikon cebong bagi pendukung Jokowi-Ma'ruf dan leksikon kampret dan kadrun bagi pendukung Prabowo-Sandi. Tampaknya scence yang mendeskripsikan situasi budaya pada saat Pilpres 2019 masih terasa sampai sekarang polarisasi tuturannya. Hal ini masihnya ditemukan dalam berbagai media sosial atau komentar terhadap Jokowi dan Prabowo yang mengaitkannya dengan leksikon cebong, kampret, dan kadrun. Sederhananya bahwa Pilpres 2019 memang telah lama usai, namun ketiga leksikon tersebut masih segar dalam pembicaraan para pendukung kedua pasangan 
calon. Meskipun faktanya, saat ini Prabowo Subianto dan Sandiaga Salahuddin Uno masingmasing bergabung ke dalam kabinet kerja Jokowi-Ma'ruf. Prabowo Subianto diangkat menjadi Menteri Pertahanan, sedangkan Sandiaga Salahuddin Uno diangkat menjadi Menteri Pariwisata dan Ekonomi Kreatif.

\section{P: Participants || 01 : orang ke-1, 02 : orang ke-2, A : adanya orang ke-3, dan U : Urutan}

\section{Bicara}

Participants dapat diselaraskan dengan $\mathrm{O} 1$ orang ke-1, O2 orang ke-2, A adanya orang ke-3, dan U urutan bicara. Alasan mendasar keduanya dilakukan penyelasaran lebih pada masing-masing mengarah pada adanya pelibatan penutur, mitra tutur, serta urutan bicara dalam suatu peristiwa tutur. Untuk itu, sudah menjadi rukun bicara yang mesti ada participants. Kehadiran leksikon cebong, kampret, dan kadrun di ruang publik baik daring maupun luring karena adanya peserta tutur: pendukung Jokowi-Ma'ruf versus Prabowo-Sandi. Di samping peserta tutur mempunyai giliran berbicara dalam penyampaian fakta bahasa.

Peserta tutur dalam konteks Pilpres 2019 dapat diinventarisasi dari kedua pasang calon: Jokowi-Ma'ruf dan Prabowo-Sandi. Dengan arti kata, peserta tutur pada Pilpres 2019 ada dua kubu yaitu kubu yang berasal dari pendukung pasangan Jokowi-Ma'ruf dan Prabowo-Sandi. Tuturan mereka terbangun berdasarkan atas pendukung loyalis pada Jokowi-Ma'ruf dan Prabowo-Sandi. Kedua pendukung ini tecermin dalam fakta bahasa yang saling melontarkan penyebutan leksikon cebong, kampret, dan kadrun di antara mereka. Sederhanya, pendukung Jokowi-Ma'ruf melontarkan leksikon kampret dan kadrun kepada pendukung Prabowo-Sandi. Sementara pendukung Prabowo-Sandi menyematkan leksikon cebong kepada pendukung Jokowi-Ma'ruf. Bahkan pola komunikasinya terbangun pada pemberian komentar terhadap suatu pemberitaan tentang kedua pasangan calon oleh kedua pendukung yang telah terpolarisasi ke dalam arus politik praktis. Saya jelaskan dengan arus politik praktis karena kedua pendukung ini tidak sekadar pada tataran wacana kebahasaan an sich tetapi lebih pada membangun narasi pemenangan pasangan yang didukungnya. Di samping membangun basis masa yang lebih kuat dalam komunitas warganet.

Pemakaian leksikon cebong, kampret, dan kadrun karena didasari adanya kontestasi antar pasangan pasang calon. Penggunaan leksikon tersebut lebih pada penurunan elektabilitas pasangan calon. Logika bahasa dimainkan agar masing-masing mitra tutur mendeskreditkan antar pasang calon, sembari mengharap calon yang diusungkannya mendulang suara akibat dari ekspresi bahasa tertentu yang disampaikan di ruang publik. Untuk itu, secara tidak disadari bahwa leksikon ini dipilih dalam rangka untuk menurunkan derajat pasangan calon. Atas dasar 
ini pula dapat ditegaskan bahwa kemenangan Pilpres 2019 tidak dapat dipisahkan dari kemenangan bahasa yang digunakan oleh partisipan.

\section{E : Ends || M : Maksud dan Tujuan Percakapan}

Ends merujuk pada tujuan pembicaraan antara penutur dan lawan tutur. Tentu ends selaras dengan $\mathrm{M}$ atau maksud serta tujuan percakapan sebagaimana yang dikembangkan oleh Soepomo Poedjasoedarmo. Setiap tuturan memang mesti memiliki tujuan karena sejatinya esensi bahasa adalah tujuan itu sendiri. Penggunaan leksikon cebong, kampret, dan kadrun tentu memiliki tujuan. Paling tidak tujuannya melemahkan calon yang dituju. Saya sampaikan dilemahkan karena peyorasi dari ketiga leksikon ini memiliki nilai rasa yang negatif bila dilekatkan dengan budaya ketimuran. Di samping tujuan politiknya ialah agar pasangan calon yang mereka usung mendulang suara sebagai akibat dari leksikon yang ditujukan kepada pasangan calon.

Dalam peristiwa tutur (speech event) bahwa komunikasi yang terjalin antara pendukung pasangan Jokowi-Ma'ruf dan Prabowo-Sandi bertujuan memenangkan masingmasing pasangan calon dalam kontestasi Pilpres 2019. Adapun pemunculan leksikon cebong, kampret, dan kadrun sebagai bentuk serangan kebahasaan pada mitra tutur. Artinya, dengan menyematkan leksokon cebong pada pendukung pasangan Jokowi-Ma'ruf dan kampret dan kadrun pada pasangan Prabowo-Sandi menjadi penciri suatu wacana tutur yang hendak digulirkan di kalangan mereka. Tentu bertujuan ada stigmatisasi negatif pada masing-masing pasangan calon. Hal ini sejatinya bahwa penyematan nama binatang kepada nomina insani menjadi sesuatu yang tidak elok dan beretika. Namun, hal ini menjadi pembiasaan di kalangan para peserta tutur kedua pasang calon karena sudah menjadi lumrah. Di samping ketiga jenis leksikon tersebut telah mengidologi di kalangan mereka hingga kini. Tampak pada sejumlah fakta bahasa yang telah disajikan terdahulu membuktikan bahwa wacana pemberitaan mengenai Jokowi-Ma'ruf dan Prabowo-Sandi masih identik di kalangan warganet dengan leksikon cebong, kampret, dan kadrun. Dalam hemat peneliti, ketiga leksikon ini menjadi sulit untuk dihilangkan karena telah mengideologi antar pendukung pasang calon.

\section{A : Act Sequence || E : Warna Emosi}

Act sequence merujuk pada suatu fakta bahasa serta bentuk ujaran yang digunakan oleh pendukung pasangan Jokowi-Ma'ruf dan Prabowo-Sandi dalam suatu peristiwa tutur (speech event). A dapat diselaraskan dengan $\mathrm{E}$ atau warna emosi sebagaimana teori yang dikembangkan oleh Soepomo Poedjasoedarmo. Leksikon cebong, kampret, dan kadrun bila dilihat dari sisi bentuk ujaran (bahasanya) berupa nomina non insani. Kata benda yang non insani ini disematkan kepada nomina insani, yaitu: Joko Widodo, Ma'ruf Amin, Prabowo Subianto, 
Sandiaga Salahuddin Uno, dan para pendukungnya. Saya mencermati bahwa mereka saling menikmati atas peristiwa tutur yang diucapkan di ruang publik. Untuk itu, dalam hemat saya Pilpres 2019 diwarnai oleh tuturan yang memuat nomina non insani berupa cebong, kampret, dan kadrun.

Fakta bahasa yang digunakan dalam kontestasi Pilpres 2019 setidaknya ada 3, yaitu: cebong, kampret, dan cebong. Leksikon cebong digunakan oleh pendukung pasangan Prabowo-Sandi guna dialamatkan kepada kepada pendukung Jokowi-Ma'ruf. Sementara leksikon kampret dan kadrun digunakan oleh pendukung pasangan Jokowi-Ma'ruf guna dialamatkan kepada pendukung Prabowo-Sandi. Pola semacam ini mengindikasikan bahwa masing-masing pendukung pasang calon telah memiliki label. Menariknya, label ini langsung diberikan oleh para pendukung yang saling berseberangan trah politik. Adapun cikal-bakal kemunculan ketiga leksikon ini lebih pada pemberian respon terhadap wacana pemberitaan yang terdapat di media sosial. Lazimnya ketika ada pemberitaan tentang Jokowi-Ma'ruf bagaikan gayung bersambut para pendukung Prabowo-Sandi turut memberikan komentar dengan mengaitkannya dengan leksikon cebong. Hal sama juga terjadi pada kasus pemberitaan tentang Prabowo-Sandi yang menggerakkan lini massa Jokowi-Ma'ruf memberikan komentar dengan leksikon kampret dan kadrun kepada mereka.

\section{K : Key $\| \mathrm{C}$ : Citarasa Penutur}

Key merujuk pada suatu nada, cara serta semangat fakta bahasa itu disampaikan. $\mathrm{K}$ senada dengan $\mathrm{C}$ atau citarasa penutur sebagaimana teori yang dikembangkan oleh Soepomo Poedjasoedarmo. Penyelarasan keduanya lebih didasarkan pada terdapatnya kesamaan pada nada suara bicara yang disampaikan oleh masing-masing pendukunga pasang calon Pilpres 2019.

Merujuk pada nada memang ini pakemnya ragam bahasa lisan. Namun, dengan demikian tidak serta merta menghilangkan key pada fakta bahasa Pilpres 2019. Pasalnya, ragam bahasa tulis menjadi representasi dari ragam bahasa lisan. Untuk itu, key dapat dilihat dari fakta bahasa dengan kehadiran diksi yang menyertai leksikon cebong, kampret, dan kadrun. Seperti tampak pada fakta bahasa yang terdapat tanda tanya sekaligus mengindikasikan tinggi dan rendahnya suatu fakta bahasa diujarkan. Sebagaimana terdapat pada data 01 yang diksi tanda tanyanya ada dua. Tentu hal ini mengindikasikan bahwa adanya intonasi tinggi pada pengucapan leksikon cebong memiliki makna tertentu. Paling tidak warganet menunjukkan rasa kekesalan serta ketidaksenangannya pada tingkah laku Joko Widodo, yang menurut pengamat sudah tidak malu melakukan kebohongan. 


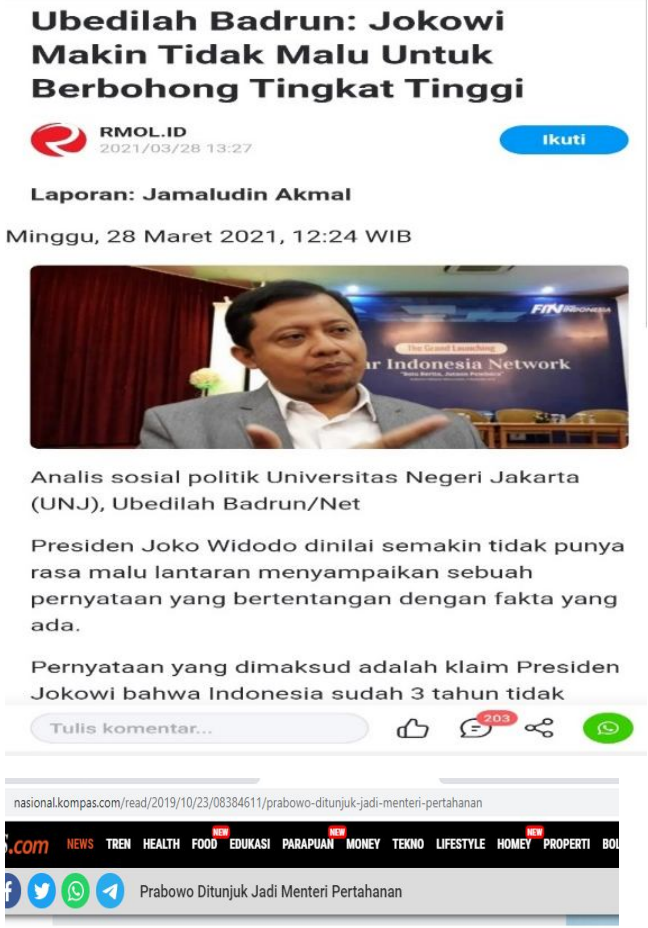

Home / News / Nasional

Prabowo Ditunjuk Jadi Menteri Pertahanan BAGIKAN:

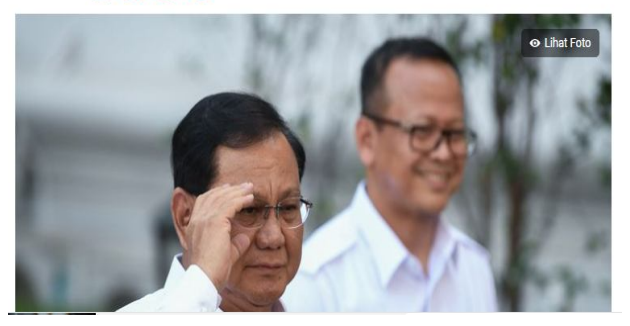

\section{Data 01}
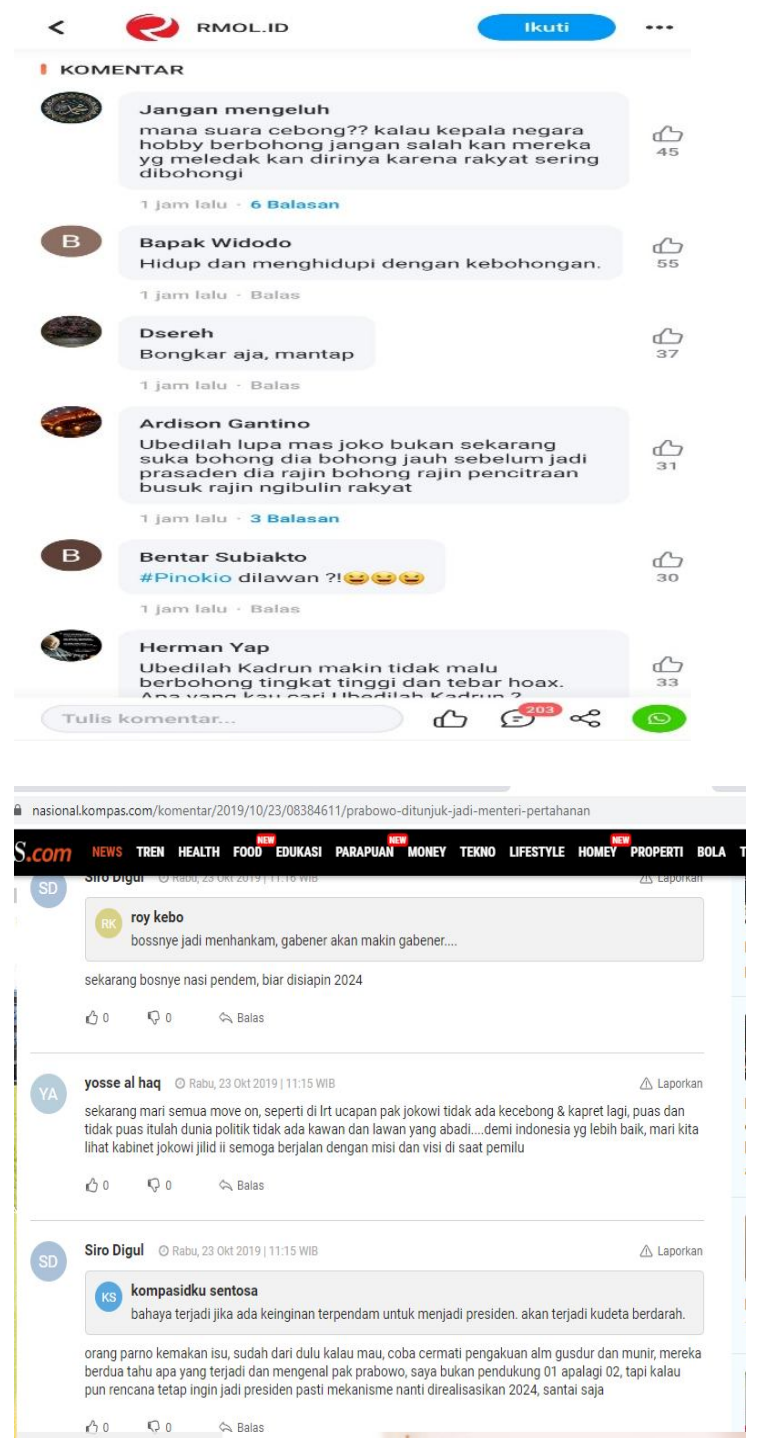

\section{I : Instumentalities || I : Instrumen atau Sarana Tutur}

Instrumentalities merujuk pada media komunikasi yang dipilih dalam menyampaikan informasi, seperti lisan dan tulisan. I dapat diselaraskan dengan I instrumen atau sarana tutur sebagaimana teori yang disampaikan oleh Soepomo Poedjasoedarmo. Penyelarasan dilakukan terhadap keduanya karena masing-masing merujuk pada suatu media pesan disampaikan, melalui lisan atau tulisan.

Dalam konteks ideologi bahasa pada Pilpres 2019 fakta bahasa yang ada adalah ragam bahasa tulisan. Pasalnya, adanya komentar tertulis dari kedua pendukung pasangan calon Jokowi-Ma'ruf dan Prabowo-Sandi. Komentar tertulis tersebut lazimnya menjadi respon terhadap wacana pemberitaan tentang Jokowi-Ma'ruf dan Prabowo-Sandi. Meskipun penggunaan ragam bahasa tulis, bukan berarti bahwa kekesalan serta kemaharahan tidak bisa 
terdekteksi. Untuk itu, dengan bantuan emotikon serta pungtuasi lainnya dapat diketahui. Seperti pada data 01 bahwa kehadiran dua tanda tanya yang memberi arti ekspresi kekesalan dan kemaran bagi warganet pasca membaca berita itu.

\section{$\mathrm{N}$ : Norm of interaction and interpretation || A : Aturan atau Norma Kebahasaan Lainnya}

Norm of interaction and interpretation merujuk pada perilaku kesopanan dalam berbicara. $\mathrm{N}$ dapat diselaraskan dengan $\mathrm{A}$ aturan atau norma kebahasaan lainnya sebagaimana teori yang dikembangkan oleh Soepomo Poedjasoedarmo. Penyelarasan dilakukan terhadap keduanya karena masing-masing mengarah pada suatu konsep norma-norma kebahasaan yang berlaku pada suatu masyarakat bahasa.

Dalam konteks dinamika komunikasi pada Pilpres 2019 yang saya khususkan pada hadirnya ketiga leksikon tersebut bahwa tampaknya sulit untuk dikatakan adanya norma kesopanan berbahasa. Pasalnya, leksikon cebong, kampret, dan kadrun memiliki nilai rasa yang negatif. Aspek negatifnya ditandai dengan disematkan adanya kesamaan nomina insani dengan nomina non insani. Artinya, menyebut seseorang dengan panggilan yang seharusnya tidak disebutkan. Terlepas dari penjelasan terdahulu karena ini sudah menjadi ideologi pada kontestasi Pilpres 2019. Untuk itu, tuturannya lebih pada metafora pada antar lawan tutur. Dalam hemat saya, inilah yang menjadi dinamika kebahasaan pada Pilpres 2019. Untuk itu, harus diterima bahwa Pilpres 2019 tidak sekadar bermuatan politik, tetapi juga sarat dengan muatan produk baru kehadiran kosakata di tengah masyarakat.

\section{G : Genre || B : Bab yang Dibicarakan}

Genre merujuk pada tipe ujaran. G dapat diselaraskan dengan B atau bab yang dibicarakan sebagaimana teori yang dikembangkan oleh Soepomo Poedjasoedarmo. Keduanya dilakukan penyelarasan karena masing-masing mengarah pada suatu konsep bab atau substansi yang dibicarakan oleh pendukung antar pasang calon. Saya mencermati bahwa kehadiran leksikon cebong, kampret, dan kadrun sangat lentur dalam pemakaiannya. Artinya, apapun topik pembicaraannya penggunaan ketiga leksikon ini kerap digunakan dalam rangka untuk mematahkan isu-isu yang berkembang di kalangan para pendukung pasang calon.

Dalam hemat saya, dalam konteks genre bahwa penggunaan leksikon cebong, kampret, dan kadrun ini sama dengan semboyan salah satu produk minuman; apapun makanannya, teh...minumannya. Artinya, apapun tema yang dibicarakan kampret, cebong, dan kadrun menjadi sesuatu diksi yang wajib ada dalam dinamika Pilpres 2019 lalu. 


\section{KESIMPULAN}

Teori SPEAKING yang disampaikan oleh Dell Hymes dapat diselaraskan dengan teori OOE MAU BICARA sebagaimana dikembangkan oleh Soepomo Poedjosoedarmo. Meskipun terjadi perbedaan jumlah fonem, namun masing-masing saling memberi penyelarasan. Seperti P dapat diselaraskan dengan O. Melalui dinamika Pilpres 2019 lalu telah memproduksi paling tidak tiga kosakata yaitu cebong, kampret, dan kadrun. Ketiganya digunakan dalam rangka ekspresi pendukung para pasang calon guna mendulang suara. Di samping Pilpres 2019 adalah pertarungan bahasa antar kontestan dan partisipan dalam memenangi kontestasi.

\section{DAFTAR PUSTAKA}

Amrullah, Latif. 2018. Slang Bahasa Inggris di Dunia Maya. Yogayakarta: Gadjah Mada University Press.

Baryadi, Praptomo. 2013. "Prof. Dr. Soepomo Poedjosoedarmo sebagai Pelopor Pendekatan Kontekstual dalam Kajian Bahasa di Indonesia" dalam Prosiding Seminar Internasional Study Bahasa dari Berbagai Perspektif dalam Rangka Ulang Tahun ke-80 Prof. Dr. Soepomo Poedjosoedarmo 5-6 Desember 2013. Yogyakarta: Diterbitkan Program Studi S2 Linguistik bekerja sama Jurusan Sastra Indonesia Fakultas Ilmu Budaya Universitas Gadjah Mada dan Gress Publishing.

Kridalaksana, Harimurti. 2008. Kamus Linguistik. Jakarta: Penerbit PT Gramedia Pustaka Utama

Aryaa, Diana J., Nicola A. McClung, Noah Katznelsonc, and Lyn Scottd. (2015). "Language ideologies and literacy achievement: six multilingual countries and two international assessments." International Journal of Multilingualism. https://escholarship.org/content/qt6b5759bt/qt6b5759bt.pdf (diakses 24 Juli 2019).

Fahrurrozi dan Andri Wicaksono. (2016). Sekilas tentang Bahasa Indonesia Catatan Mengenai Kebijakan Bahasa, Kaidah Ejaan, Pembelajaran Sastra, Penerjemahan, dan BIPA. Yogyakarta: Penerbit Garudhawaca.

Firmanzah. (2007). Mengelola Partai Politik: Komunikasi dan Positioning Ideologi Politik di Era Demokrasi. Jakarta: Yayasan Obor Indonesia.

Gading, Caecilia Petra, May Widyawari, dan Ida Zulaeha. (2016. "Representasi Ideologi dalam Tuturan Santun Para Pejabat Negara pada Talk Show Mata Najwa.” Jurnal Seloka: Jurnal Pendidikan Bahasa dan Sastra Indonesia. Vol. 5 (1) 2016).

https://kbbi.kemdikbud.go.id/entri/metafora (diakses 29 Juli 2019)

https://www.oxfordbibliographies.com/view/document/obo-9780199766567/obo9780199766567-0012.xml Language Ideology (Oxford Bibliographies) (diakses 24 Juli 2019).

Hymes, Dell. 1974. Foundation in Sociolinguistics: An Ethnographic Approach. Philadelphia: University of Pennsylvania Press.

------. 1989. "Models of the Interaction of Language and Social Life" dalam karya Bersama John J. Gumperz yang berjudul Directions in Sociolinguistics: The Ethnography of Communication. USA: Basil Blackwell Inc.

Katubi. (2008). "Bahasa dan Nasionalisme di Indonesia: Kajian Politik Bahasa." Jurnal Masyarakat Indonesia Majalah Ilmu-Ilmu Sosial Indonesia, Jilid XXXIV, No 2, 2008.

Parera, J.D. 2004. Teori Semantik. Jakarta: Penerbit Erlangga. 
Nani, Darmayanti, Nurul Hidayati, Yuliantri Fitri Permana, dan Andi Vibrianto. Bahasa Indonesia untuk Sekolah Menengah Kejuruan Tingkat Unggul (Kelas XII). Jakarta: Grafindo Media Pratama.

Putri, Anastasya dan Ahmad Toni. (2015). "Diskursus Indonesia dan Konstruksi Ideologi Media dalam Berita Debat Calon Presiden 2014 di Media Metro Tv dan Tv One.” Jurnal LISKI, Vol. 1, No 2.

Simorangkir, Imelda Malawaty dan Dewi Mutiara Indah Ayu. (2018). "Studi Penerjemahan Metafora dalam Naskah Drama di Universitas Nasional Jakarta". Jurnal Pujangga Vol. 3, No. 2, Desember 2017.

Suharyo, Surono, Mujid F. Amin. (2016). "Bahasa dan Ideologi: Mengungkap Ideologi dan Kekuasaan Simbolik di Balik Penggunaan Bahasa (Kajian Teks Media Melalui Analisis Wacana Kritis". Humanika Vol. 19 No. 1.

Surapto, Sri Samiati Tarjana, dan M.R. Nababan. (2016). "Kajian tentang Teknik, Metode, dan Ideologi dalam Penerjemahan Bahasa Politik Teks Berita Politik Internasional di Media Cetak". International Seminar Prasasti III: Current Research in Linguistics.

Silalahi, Roswita. (2005). "Metafora dalam Bahasa Batak Toba". Jurnal Ilmiah Bahasa dan Sastra Vol. 1 No. 2 Oktober Tahun 2005.

Undang-Undang Republik Indonesia Nomor 24 Tahun 2009 tentang Bendera, Bahasa, dan Lambang Negara, serta Lagu Kebangsaan

Widjojo, Muridan Satrio dan Marsudi Noorsalim. (2004). Bahasa Negara versus Bahasa Gerakan Mahasiswa: Kajian Semiotik atas Teks-Teks Pidato Presiden Soeharto dan Selebaran Gerakan Mahasiswa. Jakarta: LIPI Press.

Sutedi, Dedi. 2016. Mengenal Linguistik Kognitif. Bandung: Humaniora 